\title{
Clinical and immulogical outcomes among adult patients receiving Antiretroviral Therapy (ART) at an HIV/AIDS program in Uganda
}

\author{
Simon Muhumuza*, Julius Ssempiira, Fred Semitala, Jennifer Namusobya, Joseph Ouma, Enid Mbabazi, \\ Moses Kamya
}

From $16^{\text {th }}$ International Symposium on HIV and Emerging Infectious Diseases Marseille, France. 24-26 March 2010

\section{Background}

To evaluate clinical and immunological outcomes and the associated factors among adult patients receiving ART at MJAP, Uganda.

\section{Methods}

A retrospective cohort analysis of patient data on ART between August 2005 and June 2009 at Mulago Hospital AIDS (ISS) clinic.

Changes in Body Mass Index (BMI) and CD4 cell count, incidence of Opportunistic Infections (OIs) and mortality were compared with the patients' socio-demographics, WHO stage and CD4 count at initiation of ART, ART regimen and adherence levels. Odds ratios, 95\% confidence intervals, chi square tests, logistic regression and Cox proportional hazard model were used for analysis.

\section{Results}

Of the 4,824 patients on ART, $65 \%(3,120)$ were female, median age; 33 years (IQR: 28-40). Total follow up time was 5824.9 Person Years (PY). Median CD4+ count and BMI at ART initiation was 138 cells $/ \mathrm{mm}^{3}$ (IQR: 60-200) and $21.2 \mathrm{~kg} / \mathrm{m}^{2}$ (IQR $19.2-23.7$ ) respectively. $10.6 \%$ developed OIs, 239 (5\%) patients died. Incidence of death was 4.12/100 PY (95\% CI 3.63-4.68). Gain in CD4 count and BMI was observed in $68 \%$ and $63 \%$ of the patients respectively. Median increase in CD4 count was 174 cells $/ \mathrm{mm}^{3}$ (IQR 96-278) and mean increase in BMI was $1.5 \mathrm{~kg} / \mathrm{m}^{2}$ (S.D 2.82).

Increase in CD4 count and BMI was associated with increased income, adherence $\geq 95 \%$, WHO stages III \& IV

\footnotetext{
* Correspondence: simonmhmz@yahoo.com

Mulago-Mbarara Teaching Hospital's Joint AIDS Program (MJAP), Kampala, Uganda
}

and CD4 count $<100(\mathrm{P}<0.05)$. The risk of developing an OI was associated with CD4 count $<100$, WHO stages III \& IV $(\mathrm{P}<0.001)$ and decreasing levels of education $\left(\mathrm{c}^{2}\right.$ for trend $\left.=7.7(\mathrm{df})=1, \mathrm{P}=0.005\right)$. Mortality was higher in patients in WHO stage III \& IV (H.R 2.57, $\mathrm{P}<0.001)$ and lower in patients with CD4 count $\geq 100$, (H.R 0.32, $\mathrm{P}<0.001$ ) and adherence $\geq 95 \%$ (HR 0.55, $\mathrm{P}<0.001)$.

\section{Discussion}

Early initiation of ART, good adherence, improved income and education status are associated with increased survival and positive clinical and immunological outcomes among patients on ART.

Published: 11 May 2010

doi:10.1186/1742-4690-7-S1-P43

Cite this article as: Muhumuza et al:: Clinical and immulogical outcomes among adult patients receiving Antiretroviral Therapy (ART) at an HIV/ AIDS program in Uganda. Retrovirology 2010 7(Suppl 1):P43.

Submit your next manuscript to BioMed Central and take full advantage of:

- Convenient online submission

- Thorough peer review

- No space constraints or color figure charges

- Immediate publication on acceptance

- Inclusion in PubMed, CAS, Scopus and Google Scholar

- Research which is freely available for redistribution

Submit your manuscript at www.biomedcentral.com/submit
Biomed Central 